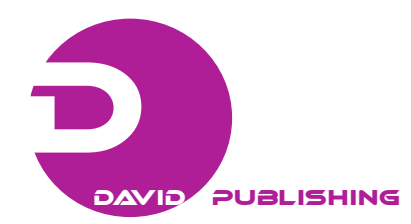

\title{
Talanga: The Tongan Way Enquiry
}

\author{
Malakai Ofanoaa, Teuila Percivala, Peter Huggarda, Stephen Buetowa
}

\begin{abstract}
This paper introduces the development and structure of this unique qualitative research methodology. The methodology was developed during research in New Zealand that explored the use of a community development/health promotion model for Tongans living in an urban environment. It is proposed that Talanga can be a methodology whereby both Tongan and non-Tongan researchers are empowered to conduct effective research with Tongans. Details of the six-step Talanga research framework are discussed along with the advantages of conducting research using Talanga as a qualitative research methodology. The paper also contrasts Talanga (interactive talking with a purpose) with Talanoa (a conversation, an exchange of ideas or thinking, whether formal or informal). The Talanga methodology would appear to be a superior approach to Talanoa in engaging in research with Tongans due to the way in which Talanga embraces fundamental Tongan cultural values.
\end{abstract}

Keywords

Talanga, faka'apa'apa, tauhi va, Tongan, Talanoa

This paper introduces "Talanga: The Tongan Way Enquiry" as a qualitative research methodology that empowers Tongans and other non-Tongan researchers to conduct effective research with Tongans. The primary reason for writing this paper is to suggest to both Tongan and non-Tongan researchers that Talanga is a better approach to research than Talanoa in view of the context and meaning of the two approaches. Although, the Talanoa approach has been used for quite sometimes, but due to the fast changes and developments in research environments, the Talanga approach is more specific and appropriate amongst the two approaches. It denotes interactive, coercive, collaborative, specific, and purposeful outcomes in research. The Talanga approach was recently developed and used during participatory action research to develop a "Tongan model" that is responsive to the needs of Tongans living in urban areas like Mangere, Auckland, and New Zealand (Ofanoa 2010). This paper will discuss how the research method emerged from its conception to birth and how Tongan and non-Tongan researchers could use it as a research tool in the fields of public health, health promotion, community development, participatory action research, and other social sciences research.

\section{EMERGENCE OF CONCEPTS: TALANGA AND TALANOA}

In everyday conversation, Tongans often use metaphorical terms like "Talanga and Talanoa" to mean the same thing. However, these two methods of communication differ from each other upon close

aUniversity of Auckland, New Zealand

\section{Correspondent Author:}

Malakai Ofanoa, 261 Morrin Rd, School of Population Health, University o Auckland, Auckland, New Zealand

E-mail: m.ofanoa@auckland.ac.nz 
Table 1. Comparison of Talanga and Talanoa Approaches in Research Enquiry

\begin{tabular}{|l|l|l|}
\hline Differences & Talanga approach & Talanoa approach \\
\hline Component & Participant centred & Researcher centred \\
\hline Reasons & $\begin{array}{l}\text { Interactive dialogue } \\
\text { Purposeful } \\
\text { Coercive } \\
\text { Empowerment } \\
\text { Collaborative }\end{array}$ & $\begin{array}{l}\text { One way dialogue } \\
\text { No purpose } \\
\text { Aggressive } \\
\text { Directive } \\
\text { Individual }\end{array}$ \\
\hline Message & $\begin{array}{l}\text { Comes from within both participants and } \\
\text { researcher experiences }\end{array}$ & Researcher led and own experiences \\
\hline Messenger & $\begin{array}{l}\text { Participants and researcher } \\
\text { People and community }\end{array}$ & Researcher \\
\hline Receiver & $\begin{array}{l}\text { Participants and researcher } \\
\text { People and community }\end{array}$ & Selected participants \\
\hline Medium & Group & Individual \\
\hline
\end{tabular}

examination of their meanings, context, and usage in conversation and research. More than Talanoa, which refers simply to talking or having a conversation, Talanga is interactive and purposeful; that is, Talanga denotes "interactive dialogue or interactive talking with a purpose" between two individuals or groups or communities. It originated from two Tongan words: "Ta" and "langa".

"Ta" is a prefix and "langa" is a suffix. "Ta" means "initiating a talk or conversation" and "langa" is "responding to a talk or conversation". Talanga then is "interactive talking with a purpose". It is much more than just talking (or Talanoa) in communication because of its purposeful and interactive nature. The differences between the two approaches are clearly described in Table 1.

The purpose of Talanga is to enable all voices to be heard, including those of disadvantaged individuals and communities. Tongans have traditionally used this form of communication in many different fora and meetings including their village fono (or monthly meeting), local debates, and other settings for formal and informal communication. In Tongan history, the local chiefs and warriors during tribal conflicts would "talanga" (or talk interactively) with each other through "fanongonongo tokoto" (person to person contacts). In this process, strategic decisions were made collectively while the warriors hid to look out for enemies. In research, Talanga is used to motivate people to control and own all aspects of any study in which they actively participate.

In contrast, Talanoa originated from two Tongan words: "Tala" means to inform, ask, or tell stories, and "Noa" which translates to nothing ordinary or with no suppression (Vaioleti 2006). It is "a conversation, a talk, an exchange of ideas or thinking, whether formal or informal. Almost always carried out face-to-face" (Vaioleti 2006: 23), it is "a personal encounter where people story their issues, their realities, and aspirations" (Vaioleti 2006: 1). Talanoa is not however a simple retelling of stories. It involves effective engagement and meaningful conversations to share and review the content of what one knows. In research, it establishes commonness between researchers' and participants' experiences and understandings; removes the power of the researcher to control the communication process; provides a familiar environment to exchange ideas freely and safely; and ignites conversations about experiences of times past or present (Vaioleti 2006).

Set against these views, Talanga appears more appropriate than Talanoa for health research because 
Talanga is more empowering, interactive, collaborative, participatory, encouraging, and purposeful. For these reasons, Tongans other Pacific and non-Pacific health researchers can use the Talanga research method to explore and gather trustworthy information, for example, through life stories, on issues that influence the health and well-being of people. Talanga also has cultural significance and more than Talanoa for Tongans. For example, the cultural values of Talanga are the golden pillars of: faka'apa'apa (respect), tauhiva (relationship caring), mamahi'ime'a (loyalty and commitment), and fakatokilalo (humility) (Ofanoa 2010). These pillars make Talanga more culturally appropriate than Talanoa for researching social, health, and other related issues that challenge Tongans and Pacific people in New Zealand.

\section{THEORETICAL STANCE}

Talanga is a qualitative research methodology that assumes "that knowledge is known-through the subjective experiences of people" (Creswell 2013), and acknowledges the value-laden and biased nature of research whereby researchers make known their values in the study through positioning themselves in research (Creswell 2013). Talanga is an "interpretative, naturalistic approach" to the world and because of its interactive nature, the researcher can "study things in their natural settings, making sense of it, or interpret phenomena in terms of the meanings people bring to them" (Denzin and Lincoln 2011; Creswell 2013). It can effectively be used when a problem or issue needs to be explored, even if there is "a need for a complex understanding of an issue" (Creswell 2007). In principle, Talanga is based on some data or information collected interactively with participants who have experienced a process issue or problems (Creswell et al. 2007). Talanga uses a rigorous set of procedures or steps to explore issues. It is a research methodology for social justice for the poor and disadvantaged people like Tongans.

\section{TALANGA RESEARCH FRAMEWORK}

As mentioned earlier, "Talanga: The Tongan Way Enquiry" was developed while conducting a participatory action research to develop a "Tongan model" to address the needs of Tongans living in urban areas like Mangere, Auckland, and New Zealand (Ofanoa 2010). The process involved in developing the Talanga framework included active listening and learning from Tongan groups and 20 key stakeholders during face to face and community meetings in Mangere in 2010. The resulting Talanga research framework entails six procedural steps that health researchers can use in conducting research (see Figure 1).

\section{Explanation of the Various Steps}

Step 1: Talking (Talanga). Talanga is the first step of the research framework. As discussed by the Tongan key stakeholders in Mangere, it is the most important step requiring communication skills of all researchers. They stated:

It is an action that one has to do in all phases of any research from the starting to the end... Researchers should be able to talanga and communicate with everyone. (Male Stakeholders)

This process involves interactive "Talking" (or Talanga) between the researcher and the participants or the target population that participates in the research enquiry. It stipulates equal power and control in communication as a two way process between the researcher and the participants to obtain reliable, factual, and valid information in the study. Its methods include: inspirational talking (talangamafana) to encourage, support, and inspire each other during the research; reciprocal talking (talangafeveitokai'aki) for sharing personal stories and wisdom; respective talking (talangafaka-matapule) to share in-depth 


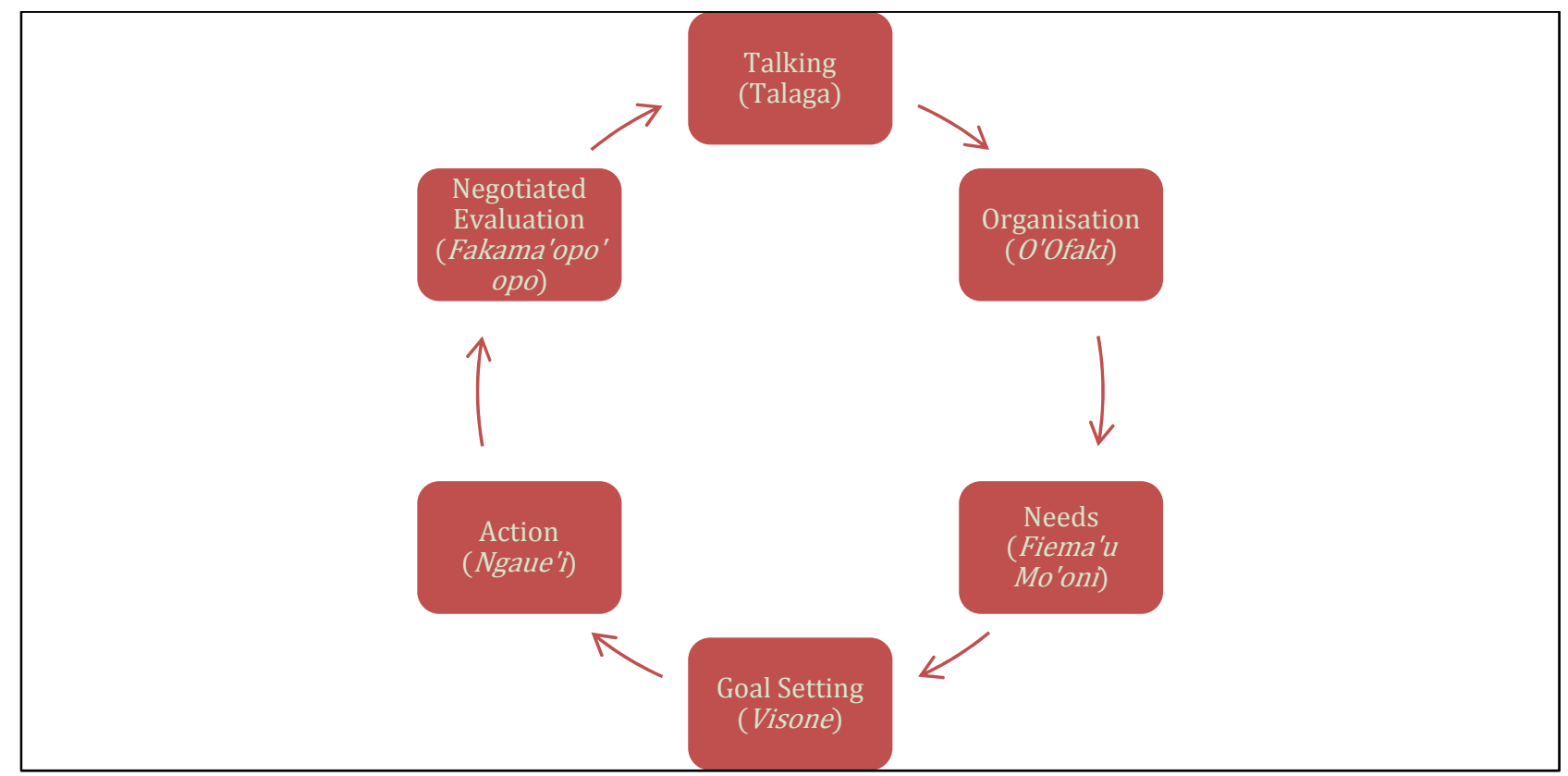

Figure 1. Talanga Research Framework.

experiences with respect; and entertaining talking (talangamalie) that involves independent, peaceful, open, and joyous talking and sharing of experiences. During this step, the researcher can use any or some of these forms of communication at any stage of the research (Ofanoa 2010).

Step 2: Organisation ('O'ofaki). The second step in the Talanga framework is called "O'ofaki". It relates to how a researcher organises Tongan participants or stakeholders for research. This step is difficult because people must fully understand the purpose of the research on them and what it requires of them from the beginning to the end. It can also be a challenge because Tongan communities have been over-researched for many years (Finau 1995). Many Tongans were not properly trained in research. Many Tongan participants in research were denied an opportunity for active involvement in research. They do not feel safe and secure because they have been disempowered in research for many years (Finau 1995). As one explained it:
In many instances, the power and control of previous researches usually rests upon the researchers, and they were treated mostly as research participants or advisors. (Male Stakeholder)

However, "O'ofaki" is culturally appropriate for organising Tongans for research. It originates from the way chickens use their wings to bring together or protect their young ones. When the young are together they feel secure, loved, cared for, and protected, and they receive warmth under their mother's wings. As all male Tongan key stakeholders explained:

'O'ofaki is more than just bringing Tongans together or to research on them. It involves protecting and safeguarding them so that they feel empowered and secured to involve fullyin research. (Male stakeholders)

Hence, in the context of setting up Tongan people for research, the 'o' ofaki approach means arranging an organizational structure in such a way as to involve Tongans early. It can lead to collaboration with the researcher to mobilise action under an appropriate 
governance structure that reflects cultural values and equal power sharing and control. According to the information collected in Mangere (Ofanoa 2010), the key principles underlying 'o'ofaki in research are: social cohesiveness (fetokoni'aki), togetherness (faaitaha), social recognition (fe'ilongaki), safety (hao), security (malu), oneness (me'ataha), caring and sharing (fetauhi'aki), reciprocity (feveitokai'aki), loyalty/commitment (mamahi'ime'a), and interconnectedness (fekau'aki). These principles are in accordance with the overall ethos of any good research project, but are especially important in the Tongan cultural context.

Step 3: Needs (Fiema'uMo'oni). The third step in the Talanga framework emphasizes the importance of identifying credible and reliable information in research related to the most deeply felt needs (or fiema'umo'oni) or wishes of the researched cohort or population. As three of the male stakeholders explained:

One of the biggest dilemmas in research is the fact that in many research outcomes, the findings are totally different... They reflected heavily the wishes and wants of the researchers themselves and not the researched population. (Mail Stakeholders)

This step is the core driver of the whole Tongan research enterprise. Strong evidence from Mangere (Ofanoa 2010) supports implementing it to respect the research needs articulated by the Tongan people. These needs relate to key concepts like: community empowerment (fakaivia e kolopekomiunitii), community control (mapule'ifakakomiuniti), community-based wishes and wants (fiema'uvivilitaha 'ae kolomoekomiunitii) and community participation and involvement in research (kaukotoa 'ae komiunitimoetahakotoape he fekumi).

Step 4: Goal setting (Visoneki he Fekumi). The fourth procedural step in the Talanga framework is Visoneki he Fekumi, which involves setting up the study goals. This task is not straight forward. It requires special skills in selecting and writing aims and objectives, which have to be simple and attainable at a cost the researchers and participants can afford. Visonekihefekumi has to be done early and requires a negotiated and collaborative effort between the researcher and the participants.

Step 5: Action (Ngaue'i). This step is the action component of the framework. It involves the development of series of actions to meet the goals of the research. As one of the oldest male key stakeholders explained it:

This is the step where all of us ask the question of who is going to do what, when, and where with what effect. (Male Stakeholder)

However, the first step is to set up an operation structure to guide the research from the beginning to the end. The second is to set up a sub-project group with its own leadership to act as the advisory group for all research actions and activities. The third is to take the actions required to meet the research timeframe. This can be broken down into a sequence of sub-goals, e.g., weekly, fortnightly, or monthly. Then a regular review or evaluation process is developed to monitor the progress and achievements of the research actions. The basic principles and indicators for taking action successfully during the research are outlined here. They include research indicators like: being community driven (fakalele 'ehekakai), community control (pule'i 'ehekakai), empowerment (fakaivia 'oekakai), equity and equality of resources (tufotufatatau he ngaahikoloangaue), loyalty/commitment (mamahi'ingaue), and sustainability (mateakiketu'uloa).

Step 6: Negotiated evaluation (Fakama'opo'opo). The last procedural step in the Talanga framework relates to monitoring and evaluation of all research activities. It involves setting weekly or fortnightly sub-goals toward achievement of the overall research goal, and weekly or fortnightly review meetings to monitor progress and set new sub-goals for the next weekly or fortnightly period. The action process of 
these research review meetings is "negotiated evaluation". As most male stakeholders emphasized:

It is equally a social process as well as an operational one, where the researcher and the participants support each other and problem solve together in a common effort to get the research done. (Male Stakeholders)

The study in Mangere (Ofanoa 2010) indicated that the principles and research indicators to support this step include: negotiated evaluation (fakama'opo'opofeloto'aki), participatory evaluation (kau e kakaihefakama'opo'opo), community control evaluation (pule'i 'ehekakai e fakama'opo'opo), and goal-based evaluation (fakama'opo'opo 'o fakatatauki he taumu'angaue).

\section{CONCLUSIONS}

This paper has introduced "Talanga: The Tongan Way Enquiry" as a new research methodology to add to literature on current research methodologies. A selected group of stakeholders suggests that it offers a suitable way to approach research among Tongan populations. It differs from the Talanoa research methodology, but "Talanga: The Tongan Way Enquiry" is a superior approach to research because it comprehensively embraces key Tongan cultural values. A sense of Tongan ownership is already felt toward the framework, and will continue to grow. However, there is a need to test the feasibility and trustworthiness of the framework in Tonga and New Zealand. We look forward to continuing this process in the hope that Talanga can support public health research in Tongan and other Pacific communities in the future.

\section{References}

Australian Health Promotion Association (AHPA). 2001. "Health Promotion and Evaluation: A Programmatic Approach." Health Promotion Journal of Australia
11:7-38.

Churchward, C. M. 1959. Tongan Dictionary. London: Oxford University Press.

Creswell, J. W. 2007. Research Design: Qualitative, Quantitative and Mixed Methods Approaches. 2nd ed. Thousand Oaks, C.A.: Sage.

. 2013. Research Design: Qualitative, Quantitative and Mixed Methods Approaches. London, United Kingdom: Sage Publication.

Creswell, J. W., W. E. Hanson, V. L. C. Plano, and A. Morales. 2007. Qualitative Research Designs: Selection and Implementation. USA: Sage Publications.

Denzin and Lincoln. 2011. The Sage Handbook of Qualitative Research. USA: Sage Publications.

Finau, S. A. 1995. "Health Research in the Pacific: In Search of a Reality." New Zealand Medical Journal 108(992):16-19.

Halapua, S. 2000. Talanoa Process: The Case of Fiji. Retrieved (http//unpan1.un.org intrados groups public documents un/unpan022610.pdf).

Kieffer, C. 1984. "Citizen Empowerment: A Developmental Perspective." Prevention in Human Services 9(1):9-36.

Kretzmann, J. and J. L. McKnight. 1993. Building Communities From the Inside Out: A Path Toward Finding and Mobilizing a Community's Assets. Chicago: ACTA Publications.

Labonte, R. and G. Laverack. 2008. Health Promotion in Action: From Local to Global Empowerment. London: Palgrave Macmillan.

Laverack, G. 2004. Health Promotion Practice: Power and Empowerment. London: SAGE Publications.

- 2007. Health Promotion Practice: Building Empowered Communities. London: MaGraw-Hill.

Marcus, G. E. 1978. "Nobility and the Chiefly Tradition in the Modern Kingdom of Tonga." Journal of the Polynesian Society 87(2):74-120.

McGrath, B. B. 2000. "Swimming From Island to Island: Healing Practice in Tonga." Medical Anthropology Quarterly 13(4):483-505.

McKenzie, D., G. John, and S. Stillman. 2007. "A Land of Milk and Honey With Streets Paved With Gold: Do Emigrants Have Over-optimistic Expectations About Incomes Abroad?" Journal of Development Economics 102(2788):116-127.

Ministry of Health. 2004. Tupu Ola Moui: Pacific Health Chart Book. Wellington: Ministry of Health.

Minkler, M. 1997. Community Organizing and Community Building for Health. New Brunswick, N.J.: Rutgers University Press.

Ofanoa, M. M. 2010. “Loto'I Tonga: A Community Development/Health Promotion Model for Tongans Living in Urban Areas." Unpublished, Doctor of Philosophy, 
University of Auckland.

Prescott, S. M. 2009. "Pacific Business Sustainability in New Zealand: A Study of Tongan Experiences." Unpublished, Doctor of Philosophy, Auckland University of Technology.

Raeburn, J. 2001. "Community Approaches to Mental Health Promotion." International Journal of Mental Health Promotion 9(3):13-19.

Raeburn, J. and I. Rootman. 1998. People-Centred Health Promotion. Chichester: John Wiley \& Sons.

Rissell, C. 1994. "Empowerment: The Holy Grail of Health Promotion." Health Promotion International 9(1):39-47.

Ritchie, J. E. 1991. "From Health Education to Education for Health in Australia: A Historical Perspective." Health Promotion International 6(2):157-163.

Taumoefolau, M. 2006. "Tongans." Pp. 271-275 in Te Ara-The Encyclopaedia of New Zealand, Settlers and Migrant Peoples of New Zealand. New Zealand: David Bateman Ltd.

Vaioleti, T. M. 2006. "Talanoa Research Methodology: A Developing Position on Research Methodology." Waikato Journal of Education 12:21-34.

World Health Organization. 1986. "Ottawa Charter for Health Promotion." Canadian Journal of Public Health 77(6):425-430.

\section{Bios}

Malakai Ofanoa, Ph.D., MHPSc, BHSc, ADHE., lecturer in Pacific health, School of Population Health, Faculty of Medical and Health Sciences, University of Auckland, New Zealand; research fields: health promotion, community development, social marketing, qualitative research, Pacific health, hepatitis $\mathrm{B}$, rheumatic fever, and stroke.

Teuila Percival, MBChB, FRACP, Head of Pacific Health Section, School of Population Health, Faculty of Medical and Health Sciences, University of Auckland, New Zealand; research fields: child health, maternal health, Pacific health, primary health care, disability, and adolescent/youth health.

Peter Huggard, EdD, MPH, Med, senior lecturer, School of Population Health, Faculty of Medical and Health Sciences, University of Auckland, New Zealand; research fields: stress, burnout, vicarious trauma, therapeutic communication, loss and grief, and Pacific health.

Stephen Buetow, Ph.D., associate professor, Department of General Practice and Primary Health Care, School of Population Health, Faculty of Medical and Health Sciences, University of Auckland, New Zealand; research fields: person-centred health care, social theory, and qualitative research. 